\title{
地域病院に打ける経皮内視鏡的胃瘦造設術（PEG）の 長期生命予後一後ろ向きコホート研究
}

Long-term prognosis after percutaneous endoscopic gastrostomy (PEG)

in a Japanese community hospital-A retrospective cohort study

\section{坂戸慶一郎12) 松 島 雅 人 $^{3)}$ 川 崎彩 子 ${ }^{344)}$ 横田 祐 介 $^{1)}$ 岩上真 吾1)

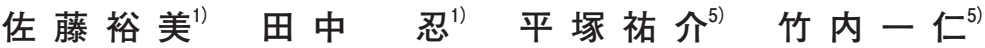

Keiichiro Sakato ${ }^{1,2)}$, Masato Matsushima ${ }^{3)}$, Ayako Kawasaki ${ }^{3,4)}$, Yusuke Yokota ${ }^{1)}$, Shingo Iwakami ${ }^{1)}$, Hiromi Sato ${ }^{1)}$, Shinobu Tanaka ${ }^{1)}$, Yusuke Hiratuka ${ }^{5)}$, Kazuhito Takeuchi ${ }^{5)}$

\section{要 旨}

目的：地域中規模病院における経皮内視鏡的胃㾇造設術（percutaneous endoscopic gastrostomy，以下「PEG」) 施行患者の長期生存率を明らかにする.

対象・方法：2004 年 1 月 1 日〜2006 年 9 月 1 日の期間にあおもり協立病院にて PEG を施行した患者を対象と し，過去の診療録を用いて調査した。累積生存率を生命表分析（Kaplan-Meier 法）にて推定し，その 95\%信頼 区間を算出した。後ろ向きコホート研究である.

結果：対象者 332 名, 平均年齢 $77.5 \pm 9.5$ 歳 (中央值 78 歳). 24 名は転帰不明であり追跡が可能だった日まで を解析に組み入れた（追跡率 $92.8 \%$ ).

累積生存率は 30 日 $90.3 \%, 1$ 年 $61.8 \%, 2$ 年 $47.9 \%, 3$ 年 $37.6 \%, 5$ 年 $21.5 \%$ であた.

結論：地域中規模病院における PEG 後の長期生存率は高次機能病院と同程度であったが，原因疾患は異なる可 能性がある。

\begin{abstract}
Introduction : The aim of this historical cohort study was to report the long-term survival rates of patients who received percutaneous endoscopic gastrostomy (PEG) at an intermediate-sized local hospital in Japan.

Subject/Method : Patients who underwent PEG between January 1, 2004 and September 1, 2006 at Aomori Kyoritsu Hospital were followed up until September 1, 2009 through a review of their medical records and telephone interviews.

The cumulative survival rate with a 95\% confidence interval was estimated by the Kaplan-Meier method. Results : A total of 332 subjects whose ages were $77.5 \pm 9.5$ years (mean $\pm \mathrm{SD}$; median, 78 years) at the start of observation. The proportion of patients whose follow-up was possible was $92.8 \%(308 / 332)$.

The cumulative survival rates were as follows : $90.3 \%$ for 30 days ; $61.8 \%$ for 1 year ; $47.9 \%$ for 2 years ; $37.6 \%$ for 3 years ; and $21.5 \%$ for 5 years.

Conclusion : In Japan, the long-term survival rate of PEG recipients at a local intermediate-size hospital was almost the same as the rates obtained in tertiary-care hospitals ; however, the reasons for performing PEG may have been different from those in the latter hospitals.
\end{abstract}

Key words：経皮内視鏡的胃瘻造設術，PEG，長期生命予後，地域病院

1）著者連絡先：坂戸慶一郎 健生黒石診療所〔⿳亠 036-0356 青森県黒石市ちとせ 3-6〕 E-mail ： sakato-k@fa3.so-net.ne.jp

2) 青森保健生活協同組合 あ扔もり協立病院

3）東京慈恵医科大学 総合医科学研究センター・臨床疫学研究室

4) 医療法人財団 慈生会 野村病院

5）津軽保健生活協同組合＼cjkstart健生病院 


\section{背景と目的}

経皮内視鏡的胃瘻造設術 (percutaneous endoscopic gastrostomy, 以下 $\lceil\mathrm{PEG}\rfloor)$ は, 1980 年代に紹介 ${ }^{1)}$ れて以降, 嚥下障害や摂食障害の患者に対して数多く 行われている。しかし我が国ではその疫学デー夕にそ しく, 年間の PEG 施行件数を明確に示すデー夕は見 当たらない（2004 年前後の年間新規 PEG 施行件数は 10 万例前後と推定 ${ }^{2}$ されている). この治療が患者の 生命予後の改善, 身体的精神的機能の向上, QOL の向 上にどれくらい寄与するか等についても，未だ解明さ れていない点も多い.

臨床の現場において，PEG を施行するかどうかにつ いては, 有用性とその限界, 危険性について患者本人・ 家族と慎重に相談して決めることが必要となる。その 際, PEG 施行後の長期生命予後について, 個別性を考 慮しつつも一般的なデー夕を示すことは, 重要な情報 の一つとなるだろう.

PEG 施行後の長期生命予後に関して, 最も多くの患 者を長期に追跡した海外の研究 ${ }^{3}$ では, PEG または手 術による胃瘦造設術を行った 81105 人を対象に調査 ᄂ, 30 日生存率 $76.1 \%, 1$ 年生存率 $37.0 \%, 3$ 年生存 率 $18.7 \%$ と報告されている。一方, 最近日本に扔いて 行われた 931 名を対象とした多施設共同研究4)では, 1 年生存率 $66 \%, 50 \%$ 生存期間 753 日，25\%生存期間 1647 日であり, 海外における成績よりかなり良好な結 果であった。ただし, 対象となった医療機関は $\lceil$ community and tertiary hospitals」とされ, この結果 が一般的な二次医療機関である地域中規模病院でも当 てはまるかは不明である。我が国において，地域中規 模病院での PEG 施行後の長期生命予後に関する研究 はそしく,プライマリ・ケアセッティングにより近い 状況での妥当性・信頼性の高いデー夕を必要としてい る.

あ招もり協立病院は人口約 30 万人の地方都市（青 森市）にあり ${ }^{5)}$, 病床数 223 床と中規模な二次医療機 関で, 平均的な地域病院と考えられる.

今回の研究は, 当院での PEG 施行後の長期生命予 後を調查することによって, 我が国の地域中規模病院 に扔ける PEG 施行患者の長期生存率を明らかにする ことを目的として行った。

\section{方 法}

\section{1. 対象}

適格基準は, 2004 年 1 月 1 日〜2006 年 9 月 1 日ま での間に, あおもり協立病院にて PEG を施行した患
者全例とした．また，この期間中に同一症例に対し複 数回 PEG を施行している場合は, 初回を追跡開始日 とし, 2 回目以降を除外した.

あ招もり協立病院では全例で pull 法苜を用いてい る。これは胃内に挿入したガイドワイヤーに胃瘦カ テーテルを結び付けて腹壁外に引き出す造設方法であ る.

\section{2. 方法}

研究デザインは後ろ向きコホート研究である.

本研究のフィールドとなるあ扔もり協立病院は, 病 床数 223 床, 診療科数 9 , 第 2 次救急医療機関, 急性期 病院で, 卒後臨床研修教育関連病院となっている $(2012$ 年 1 月現在).

あおもり協立病院の内視鏡室記録および入院診療録 より, PEG 施行年月日, 性, 年齢, PEG 施行に至った 原因疾患, 他の併発疾患（導入時）を抽出した.

上記コホートを 2009 年 9 月 1 日時点まで追跡し, 診療録の最終生存確認日をもって生存とした. PEG 施行後に他の施設に転出していた場合には, その施設 に文書を郵送し問い合わせを行った．また，自宅に 戻った場合は, 本研究の目的を説明した文書を送付し, 電話連絡にて口頭で同意が得られた場合は状沉を確認 した.

PEG 施行に至った原因疾患については, 調查時に予 め分類する診断名一脳血管障害（脳梗塞, 脳出血, も膜下出血, その他), 廃用症候群, 認知症, 不明, そ の他一を用意し，K．S，S. I，S. Tの 3 名がそれぞ れ診療録をもとに分類した。 どの疾患に該当するかの 判断は各主治医によるが, 脳血管障害は神経学的所見 と画像所見より判断し, 廃用症候群は「肺炎や手術な ど何らかの負荷の後に ADL が低下し癌などの明らか な異常を指摘し難い状態」とした。

研究の目的・ 内容と, 本研究に関する問い合わせ方 法や不同意の場合の申し出について明記した文書を, あおもり協立病院と附属診療所に揭示し, ホームペー ジに揭載した.

得られたデー夕をあおもり協立病院にて保管し, 患 者個人名をデー夕から分離した上で, デー夕の集計・ 管理・解析は研究担当者のみが行った. 本研究を行う にあたり, あおもり協立病院医療倫理委員会にて審査 を受け承認を得た．また，研究に要した費用は全てあ 抢もり協立病院が負担している.

\section{解 析}

患者の臨床情報において年齢はその平均值士標準偏 
表 1 研究対象患者のプロフィール

\begin{tabular}{|c|c|c|c|c|c|}
\hline & & & 女性 & 男性 & 合計 \\
\hline \multirow[t]{5}{*}{ 年齢（歳） } & $\leqq 60$ & & 4 & 13 & $17(5.1 \%)$ \\
\hline & $60-69$ & & 19 & 28 & $47(14.2 \%)$ \\
\hline & $70-79$ & & 54 & 61 & $115(34.6 \%)$ \\
\hline & 80-89 & & 84 & 43 & $127(38.3 \%)$ \\
\hline & $90 \leqq$ & & 18 & 8 & $26(7.8 \%)$ \\
\hline \multirow[t]{8}{*}{ 原因疾患 } & 脳血管障害 & & 66 & 44 & $110(33.1 \%)$ \\
\hline & & （脳梗塞 & 48 & 32 & 80) \\
\hline & & （脳出血 & 13 & 10 & 23) \\
\hline & & (<も膜下出血 & 5 & 2 & 7) \\
\hline & 廃用症候群 & & 58 & 79 & $137(41.3 \%)$ \\
\hline & 認知症 & & 22 & 7 & $29(8.7 \%)$ \\
\hline & 不明 & & 10 & 8 & $18(5.4 \%)$ \\
\hline & その他 & & 23 & 15 & $38(11.4 \%)$ \\
\hline
\end{tabular}

差を示し，中央値を併記した。また表 1 には性別年齢 階級別度数分布を示した. 生命予後については, 累積 生存率を生命表分析（Kaplan-Meier 法）にて推定し, 95\%信頼区間（CI）を算出した，原因疾患による累積 生存率曲線の差の検定には Log-rank 検定を用いた. 解析にはSTATA 10.1 を用いた7).

\section{結 果}

2004 年 1 月 1 日〜 2006 年 9 月 1 日までの $\mathrm{PEG}$ 施行 件数は 341 件であったが, そのうち, 同一症例が重複 して行った 9 件分を除外した。

対象者 332 名, 平均年齢 $77.5 \pm 9.5$ 歳（中央値 78 歳)。男性 153 名 (平均年齢 $74.7 \pm 9.7$ 歳, 中央值 76 歳), 女性 179 名 (平均年齢 $79.9 \pm 8.7$ 歳, 中央値 82 歳)であった（表 1)。2009 年 9 月 1 日現在で, 生死ま たは死亡年月日が不明な人数は 24 名であり, それら は追跡が可能だった日までを解析に組み入れた（追跡 率 $92.8 \%$ ).

累積生存率は 30 日 $90.3 \%(95 \% \mathrm{CI}: 86.6-93.0 \%)$, 1 年 $61.8 \%(95 \% \mathrm{CI}: 56.2-66.9 \%), 2$ 年 $47.9 \%(95 \%$ $\mathrm{CI}: 42.3-53.3 \%), 3$ 年 $37.6 \%(95 \% \mathrm{CI}: 32.2-43.0 \%)$, 5 年 $21.5 \%$ (95\% CI : 15.9-27.7\%) であった（図 1).

また原因疾患としては, 廃用症候群 $41.3 \%$, 脳血管 障害 $33.1 \%$ が多かった（表 1).

原因疾患別生存率曲線を図 2 に示す。原因疾患で生 存率曲線に有意差は認められなかった（Log-rank 検 定 $\mathrm{p}=0.36$ ).

\section{考 察}

日本の地域中規模病院での PEG 施行後の長期生命 予後については,「中規模病院」の定義は定まったもの

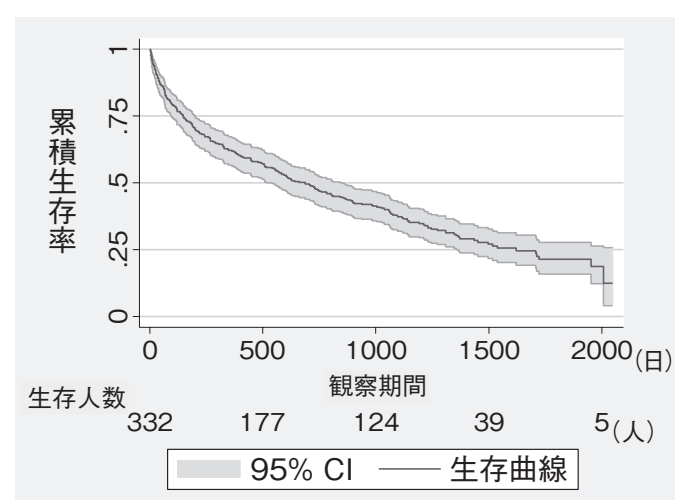

図 1 PEG 施行後の累積生存率曲線

はないため病床数 300 床未満と仮定すると, 高橋らに よる 367 名を対象とした研究8) にて 1 年生存率 $50 \%$ 前 後, 2 年生存率 $30 \%$ 前後, 3 年生存率 $20 \%$ 前後との報 告がある。しかし残念ながら追跡方法・最終転帰不明 の症例数 (追跡率) とその扱いは不明であり, デー夕 の妥当性を検証できない. その他, 病床数 300 床未満 の医療機関で 300 名以上を対象とした研究は無く, 今 回の研究で当院での PEG 施行後の長期生命予後を明 らかにすることによって, 地域における PEG の長期 生命予後に関する情報を提示した。

各時点の累積生存率を海外 ${ }^{3}$ 抢よび日本の多施設共 同研究4) と比較すると (図 3), 本研究においては, 日 本の多施設共同研究) と比較して 30 日生存率は若干 低めではあるが 1 年生存率はほぼ同等であり, 海外の データと比べ良好であった。

また, PEG 施行に至った原因疾患について, 日本の 多施設共同研究 $15 \%$ となって抢り, 本研究の結果と大きく異なってい る. 当院では「虚弱高齢者が, 感染症などを契機に更 


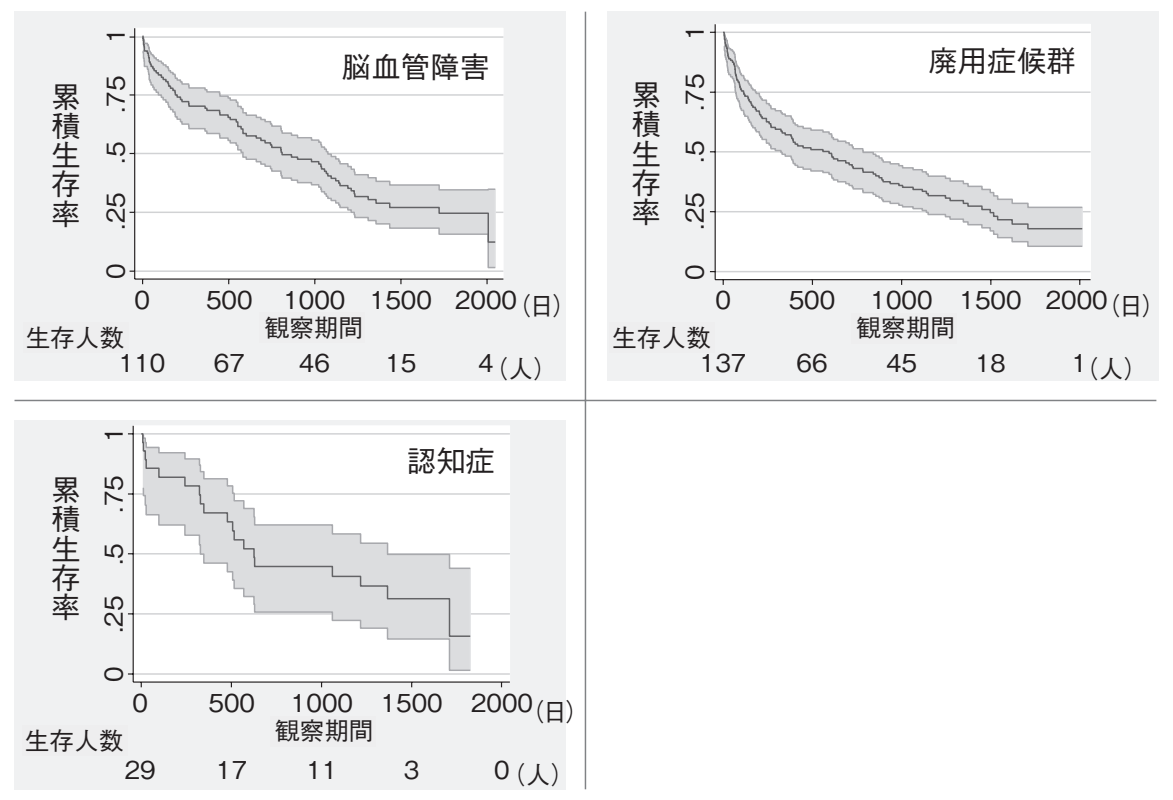

図 2 原因疾患別生存率曲線

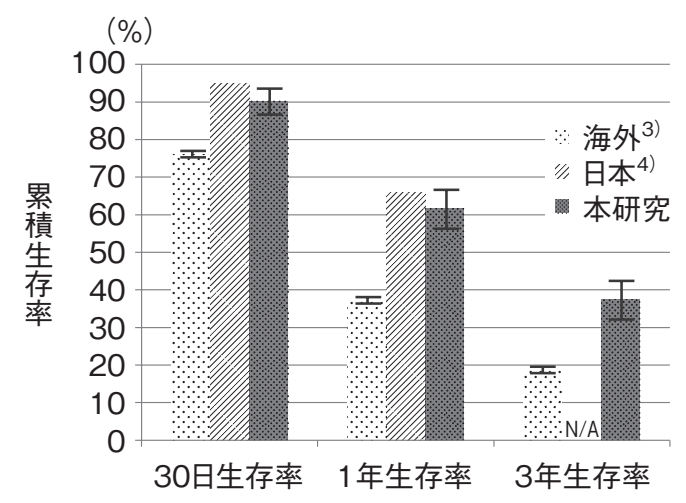

図 $3 P E G$ 施行後累積生存率: 先行研究との比較

表 2 先行研究の年代等の比較

\begin{tabular}{|c|c|c|}
\hline & 参考文献 & 参考文献) \\
\hline 研究の国 & 米国 & 日本 \\
\hline 研究の対象 & $\begin{array}{l}\text { 入院して胃瘻を造設し } 1991 \text { 年に退院となった } \\
65 \text { 歳以上のメディケア患者 } 81105 \text { 例 }\end{array}$ & $\begin{array}{l}2005 \text { 年 } 1 \text { 月 } 1 \text { 日〜2008 年 } 12 \text { 月 } 31 \text { 日に PEG } \\
\text { を施行した } 65 \text { 歳以上の患者 } 931 \text { 例 }\end{array}$ \\
\hline 対象施設 & 米国全体（HMOs を除く） & 地域病院または高次機能病院 46 病院 \\
\hline 対象年歯令 & 75 歳以上が $74.5 \%$ & $81.4 \pm 7.8$ 歳 \\
\hline 調査時期 & 記載なし & 2009 年 10 月現在まで \\
\hline 手技 & $\begin{array}{l}\text { PEG 施行 } 59969 \text { 例 } \\
\text { (詳細な記載は無し) } \\
\text { 手術による胃瘻造設 } 21136 \text { 例 }\end{array}$ & 記載無し \\
\hline PEG 施行の原疾患（最多） & Cerebrovascular disease & 脳血管障害 \\
\hline 上記の診断根拠 & 各病院で付けられた病名を分類 & $\begin{array}{l}\text { 研究時に病名を提示 } \\
\text { 診断基準の記載は無し }\end{array}$ \\
\hline
\end{tabular}


に衰弱し経口摂取困難となった」といういわゆる廃用 症候群と思われる場合が多く, 原因を単一の臟器障害 に帰結させるのが困難であった．地域中規模病院にお いては高次機能病院の PEG 施行対象者とは原因疾患 が異なる可能性が示唆される。今後, PEG に至った原 因疾患の診断基準や過程を共通化した比較研究が望ま れる.

PEG 施行に至った原因疾患別の長期生存率を検討 したが (図 2)，それぞれの原因疾患について，本研究 では長期生存率に有意差を認めなかった。

認知症に関しては, PEG が長期生存率や肺炎の予防 に寄与するかどうかという点で懐疑的な報告910) がさ れており, PEGの適応について慎重な判断が必要であ る. 本研究では PEG 施行に至った原因疾患として 29 名の症例があり，その長期生存率は脳血管障害との有 意差が無かった。しかし，口腔ケア・リハビリテーショ ン・食事の工夫や食事介助等の適切な介入が尽くされ ていたかについての検討が必要であり，経口摂取が可 能な状態であった方にPEG を行っていた場合，実際 よりも生命予後について良好な結果となってしまう恐 れがある。 また, 原因疾患の診断が正確でない場合も， 同様に生命予後の結果が良好となる。

先行研究の特徴を表に示す通り (表 2), PEG 施行の 年代や患者背景, PEG の施行・管理方法, 原因疾患の 判定基準などがそれぞれ異なるため, 厳密な比較検討 はできない．また本研究は後ろ向きコホート研究であ り，原因疾患の判定の精度に問題が残ることから，今 後は原因疾患の判定基準を明確にした前向き研究が必 要であろう. 更に, PEGを行う集団と行わない集団と の比較を行った研究では無いため, PEGをした方がい いのかどうかの直接的な評価ができるものではない.

\section{まとめ}

我が国の地域中規模病院であるあおもり協立病院に おける PEG 施行患者の長期生存率について明らかに した．海外の報告に比べて良好ではあったが，3 年生 存率は $37.6 \%$ と, 必ずしも長期の生存が見込めるもの では無かった．今後の PEG 施行の際の一判断材料と なると考えられた。

また高次機能病院と地域中規模病院では PEG 施行
の原因疾患が異なる可能性が示唆され，我が国のプラ イマリ・ケアセッティングに近い状況での PEG の有 用性に関する更なる研究が必要と思われた。特に原因 疾患と長期生命予後の関係については, 原因疾患の判 定基準を明確にした前向き研究が必要である。

\section{謝辞}

本研究は文部科学省「地域医療等社会的ニーズに対 応した質の高い医療人養成推進プログラム」(医療人 GP）での「プライマリケア現場の臨床研究者の育成」 プログラムの支援によって行われた。

\section{参考文献}

1) Gauderer, M. W., Ponsky, J. L. et al. : Gastrostomy without laparotomy: a percutaneous endoscopic technique. J Pediatr Surg. 1980, vol. 15, p. 872-875.

2) 胃ろうと栄養 TEXT BOOK ; 責任編集 鈴木裕 ; NPO 法人 PEG ドクターズネットワーク, 第 1 版第 1 刷, p. 14

3) Mark D. Grant, et al. : Gastrostomy placement and mortality among hospitalized Medicare beneficiaries. JAMA. 1998, vol. 279, p. 1973.

4) Suzuki, Y, Tamez, S. et al. : Survival of geriatric patients after percutaneous endoscopic gastrostomy in Japan. World J Gastroenterol. 2010, vol. 16, no. 40, p. 5084-5091.

5）平成 17 年国勢調查結果第 1 次基本集計. 総務省統計 局

http://www.stat.go.jp/data/kokusei/2005/index.htm 2011 年 2 月 11 日アクセス

6）西口幸雄, 矢吹浩子. 胃ろうケアと栄養剤投与法, 照 林社, p. 64-65, 2009.

7) StataCorp. 2007. Stata Statistical Software: Release 10. College Station, TX : StataCorp LP.

8）高橋美香子, 佐藤満雄ら. 経皮内視鏡的胃瘦造設術 (PEG) の造設手技と合併症, 長期経過についての検 討：綜合臨林. 1997, vol. 46, no. 7, p. 2028-2032.

9) Finucane, T.E, Christmas, C. et al. Tube feeding in patients with advanced dementia- a review of the evidence. JAMA. 1999, vol. 282, no. 14, p. 1365-1370.

10) Garrow, D., Pride, $P$, et al. : Feeding alternatives in patients with dementia : examining the evidence. Clin Gastroenterol Hepatol. 2007, vol. 5, no. 12, p. 1372. 